\title{
Public transport strategy: Minimal service vs. competitor to the car
}

\author{
Cecília Silva \\ Faculty of Engineering, University of Porto \\ CITTA Research Centre for Territory \\ Transport and Environment \\ ccsilva@fe.up.pt \\ Nayanne Castro \\ University of Porto \\ nayanneguerra@gmail.com
}

\author{
Catarina Cadima \\ University of Porto \\ cadima.catarina@gmail.com
}

\author{
Aud Tennøy \\ Institute of Transport Economics- \\ Norwegian Centre for Transport Research \\ Aud.Tennoy@toi.no
}

\begin{abstract}
With regard to public policy for public transport services, two dominant approaches are found: the provision of minimal services to the car-less population, or the provision of a service that competes directly with the car (in terms of time, cost, convenience, etc.). Increased acknowledgement of the need to mitigate traffic growth and reduce greenhouse gas (GHG) emissions has led to a growing need to shift from the former to the latter, encouraging the use of public transport.

This paper sets out to explore whether competitiveness with the car is a priority for the public transport planning of medium-sized European cities, as well as whether the change in European regulation (European Commission, 2007) has managed to contribute to the acceptance of this priority. In this study, we take a closer look at a country undergoing significant regulatory and procedural transformations. An exploratory analysis is conducted regarding plans, actions, and development projects in recent years in four Portuguese municipalities. Relevant planners and transport authorities are interviewed on matters such as how local policies and plans favor public transport; how the planning process was implemented; the actors involved; and the support tools used to achieve the established goals.

The findings reveal that relative competitiveness of public transport is considered important by planning practitioners. Nevertheless, other concerns seem to be more timely, such as, providing minimal services, restructuring existing networks, and budget constraints. The results suggest that changes in the planning process have been overwhelming and are seen as restricting the steps required toward making public transport more competitive vis-à-vis the car. So far, local authorities recognize the potential of adding relative competitiveness concerns in the future, as well as the added value of planning support tools capable of revealing such relative competitiveness.
\end{abstract}

\section{Article history:}

Received: March 13, 2021

Received in revised form: July 29, 2021

Accepted: September 6, 2021 Available online: December 6, 2021

Copyright 2021 Cecília Silva, Catarina Cadima, Nayanne Castro \& Aud Tennøy http://dx.doi.org/10.5198/jtlu.2021.1982

ISSN: 1938-7849 | Licensed under the Creative Commons Attribution - Noncommercial License 4.0

The Journal of Transport and Land Use is the official journal of the World Society for Transport and Land Use (WSTLUR) and is published and sponsored by the University of Minnesota Center for Transportation Studies. 


\section{Introduction}

In recent years, increased acknowledgement of the need to mitigate urban problems - such as social cohesion, greenhouse gas emissions, traffic congestion, parking pressure, public health - has led to a growing concern as to how planning practitioners can develop land-use and transport systems in a more sustainable direction (Banister et al., 2015; Holden et al., 2017; Tennøy et al., 2016). One strategy for achieving this is to improve, for instance, public transport quality, so as to make it competitive with the private car (Buehler \& Hamre, 2015; Buehler \& Pucher, 2011; Hitge \& Vanderschuren, 2015).

Following the introduction of recent European regulations (e.g., Regulation EC No. 1370/2007) (European Commission, 2007), Portugal has recently implemented a new regulatory framework for public transport that has high potential for improving public transport's competitiveness in comparison to the car - the Portuguese RFPPT (Regulatory Framework for Passenger Public Transport, law No. 52/2015). The RFPPT (2015) transferred the planning, development, management, investment, funding and supervision of the public transport systems from the national to local authorities. This change in scale has significant potential, when one considers that land use and sustainable mobility strategies are mainly enforced at the local level, complementing municipal Master Plans and Sustainable Mobility Plans. Public transport strategy is now the responsibility of municipalities and supra-municipal bodies (i.e., those belonging to Metropolitan Areas or Intermunicipal Communities). In a period of four years, Portuguese municipalities were required to build a public transport strategy, define the networks and service level, and open calls for tenders for those services.

Based on the new regulatory framework, this paper explores if and how public transport competitiveness has been considered in the new plans and policy processes of four Portuguese municipalities. ${ }^{1}$ It is organized as follows. The next section explores best practice in increasing public transport competitiveness versus the private car. Section 3 presents our research approach in greater detail and the four case studies. Section 4 analyses and discusses the current processes. The paper ends with a final reflection on lessons learned from this context.

\section{Public transport competitiveness vs private car}

In general terms, relative competitiveness refers to the ability to overtake competitors in conditions of free competition, usually understood as the comparison of costs, time and comfort between two or more modes of transport ( $\mathrm{Li}$ et al., 2018). Accordingly, this paper defines relative public transport competitiveness as the ability to attract travelers to use public transport over other modes of transport - particularly the private car. Planning for public transport competitiveness is a strategy aimed at making the option of public transport more attractive, particularly over the private car, so that it can be considered as a priority option for people.

Public transport plays a vital role in cities providing access between destinations such as the home, workplaces, school, public healthcare establishments, services and shopping (Cervero, 2014; MirallesGuasch et al., 2014; Poliak, Poliakova et al., 2017). Regarded as an affordable and democratic transport, public transport has the potential to support social cohesion, providing access to certain activities to the most vulnerable population groups (low-income groups, students and the ageing population). Public transport also has the potential to reduce traffic congestion and GHG emissions, as well as parking demand (Cervero, 2013; Freudendal-Pedersen, 2020; Lee et al., 2019; Sallis et al., 2014).

\footnotetext{
${ }^{1}$ This research is part of a larger project - IPTC Improving Public Transport Competitiveness versus the Private Car - develop-
} ing similar research approaches in Portugal and Norway. 
In most medium-sized cities, public transport demand is weakening (Li et al., 2018; Poliak et al., 2017). Urban sprawl and the increase in car use cause losses in trip frequency and reliability of public transport services, having a negative effect on public transport competitiveness, at the same time that losses in demand and relative competitiveness refeed each other (Litman, 2018; Marquet \& MirallesGuasch, 2018; Mohino \& Ureña, 2020; Poliak et al., 2017). While many smaller cities have regarded public transport as a secondary transport mode, mostly relevant for residents without access to the car, more recent concerns with sustainable mobility have shown the importance of seeing public transport as an alternative to the car (Banister, 2008; Marquet \& Miralles-Guasch, 2018; Mohino \& Ureña, 2020).

Public transport attractiveness depends on frequency of service, network coverage, comfort and reliability (Curtis \& Scheurer, 2010; Kenyon \& Lyons, 2003; Litman, 2018). Indeed, attractiveness is also associated with urban density, design and mixed-use (Cervero \& Kockelman, 1997; Naess, 2006; Pinho et al., 2015), and is related to factors such as speed, capacity, cost, travel time and attitudes (Banister, 1994; Thomas \& Bertolini, 2017).

The use of transit-oriented development (TOD) is suggested as a land-use strategy for fostering public transport competitiveness versus the private automobile, merging, as it does, transport engineering and planning, land-use planning and urban design to provide comprehensive solutions for contemporary urban problems (Ibraeva et al., 2020; Papagiannakis et al., 2021). Thomas and Bertolini (2017) argue that success of TODs depends on certain key elements, such as: 1) Policy Consistency (e.g., specific station areas, transit corridors, and other transit-supportive and non-motorized-supportive landuse planning); 2) Vision Stability (e.g., city-regional vision for land-use/transport planning or urban sustainability); 3) Government Support (e.g. fuel taxes, urban regeneration in the proximity of stations, policy and provincial funding for infrastructure); and 4) Goal Achievement Consistency (for a detailed and recent review see Ibraeva et al., 2020).

Today, it is now clear that transport planning must integrate land-use policies and car restrictions so as to improve public transport competitiveness (Curtis \& Scheurer, 2017; Lee et al., 2019; Pucher \& Buehler, 2017; Tennøy et al., 2016). Also, that the effective implementation of hard measures, namely car restrictions, require citizen support (Banister, 2008; Bertolini, 2020). Table 1 presents a summary of a number of good practices. 
Table 1. Good practices related with public transport competitiveness

\begin{tabular}{|c|c|}
\hline & Measures \\
\hline $\begin{array}{l}\text { (i) public transport service } \\
\text { quality }\end{array}$ & $\begin{array}{l}\text { - New bus lanes and synchronized schedules (increase and improve service) [1],[5],[9] } \\
\text { - Reliability and availability (how frequently service is available) [9] } \\
\text { - High-quality bus corridors (speed) [1],[2],[4],[9] } \\
\text { - Segregated bus lanes (safety) [1],[2],[4],[9] } \\
\text { - Intermodal connections (coordination, cooperation and interaction) [1],[2],[4],[5] } \\
\text { - Bus stop access for pedestrians, cyclists and disabled people [1],[2],[5] } \\
\text { - Platform for multimodal mobility information and services [1],[2],[4],[5] } \\
\text { - Reducing prices (financing and lower fares) [1],[2],[4],[5],[9] } \\
\text { - Integrated ticketing and green mobility card [1],[2],[4],[5],[11] } \\
\text { - Traveler information system (Information provision) [4],[5],[11] } \\
\text { - Smart traffic lights (flows can be coordinated more efficiently) [4] } \\
\text { - DRT [5] }\end{array}$ \\
\hline (ii) car restrictions & $\begin{aligned} \text { - } & \text { New transport hierarchy (hierarchical structure including pedestrian and cyclist) } \\
& {[5],[7],[10] } \\
\text { - } & \text { Parking restrictions [1],[2],[3],[7],[9],[10] } \\
\text { - } & \text { Road pricing [1],[2],[4],[7] } \\
\text { - } & \text { Road narrowing or deflections (chicanes) [2],[4] } \\
\text { - } & \text { Mini-roundabouts [2],[4] } \\
\text { - } & 30 \mathrm{~km} / \mathrm{h} \text { and other speed limits [1],[2],[4] } \\
\text { - } & \text { Modernizing the traffic management system [1],[2],[4] }\end{aligned}$ \\
\hline (iii) land use & $\begin{array}{l}\text { - Development density, [1],[2],[4],[8],[9] } \\
\text { - Mixed uses (reducing distances and the physical separation of activities), } \\
\text { - Controlling urban sprawl, [1],[2],[3],[4],[8],[10] } \\
\text { - Urban design (networks without spatial discontinuities) [1],[2],[4],[5],[6],[7] } \\
\text { - Improving proximity location and facilities (stops, stations and transfer centers) [5],[6] } \\
\text { - Developing new housing around stations }[6],[8],[9] \\
\text { - School proximity [1],[2],[3],[8] } \\
\text { - Replace parking and road space to other functions }[1],[2],[4] \\
\text { - Cycle networks and pedestrian areas \& routes (Improving the accessibility of urban areas to } \\
\text { enable people to travel more by alternative modes) [1],[2],[3],[4],[6],[8] }\end{array}$ \\
\hline
\end{tabular}

Legend: [1]-konsult (http://www.konsult.leeds.ac.uk/); [2]-VTPI (www.vtpi.org); [3]-BooST (https://boost.up.pt/en/roadmap/measures-selection/); [4]-CIVITAS (https://civitas.eu/mobility-solutions); [5]-(Poliak et al., 2017); [6]-(TFL, 2017); [7]-(Banister, 2008); [8]-(Ibraeva et al., 2020); [9]-(Litman, 2018); [10]-(Litman, 2011); [11]-(Lee et al., 2019)

In light of these concerns, public transport strategy needs to shift from the provision of minimal services to car-less inhabitants, to the provision of high-quality services that are able to compete with the car. The aim becomes one of capturing regular car-users, thus increasing the number of so-called choice riders of public transport (Benenson et al., 2011; van Lierop \& El-Geneidy, 2018). In many cities, public transport strategy is focused on maximizing coverage, i.e., making sure that as many people as possible have access to the public transport service, particularly those without access to a car. This is a valid planning aim, particularly with regard to social equity concerns. However, most cities suffer from severe financial constraints to offering such services, a situation that is reinforced by the low financial viability of public transport in dispersed urban contexts (which are dominant in many cities). This reality leads most cities to compensate for a high degree of coverage with low service levels, such as, low frequencies and longer in-vehicle travel distances, particularly for low density urban areas. These minimal services, while inclusive in their physical outreach, end up providing sub-standard services to all those people they were aimed at (people without access to a car who have no other choice but to use public transport), effectively pushing away anyone with the ability to use a car. 
Silva et al., (2020) suggests comparing accessibility across modes to reveal relative competitiveness between public transport and the car. Revealing relative competitiveness of public transport will certainly point out drawbacks of limited policies (as the ones referred to above). Planning support tools such as relative accessibility measures could be valuable allies in bringing about the potential introduced by the regulatory framework. From the perspective of planning practice, it helps to identify inequalities in land use and transport systems to help formulate policies to overcome them. Also, these instruments can be useful to justify decisions and support strategies (Silva et al., 2020).

\section{$3 \quad$ Research design}

\subsection{Research question and process}

Bearing in mind the importance of public transport competitiveness for sustainable mobility, this paper addresses the following research questions: 1) Is public transport competitiveness a priority in public transport planning of medium-sized European cities? and 2) has the European regulation change in 2007 contributed to the uptake of this priority by medium-sized cities? In this paper, we will explore lessons learned from the Portuguese context. An exploratory analysis was conducted in four Portuguese municipalities - Oporto, Maia, Santo Tirso and Viseu. The research involved documental analysis (presented in section 4.1) and semi-structured interviews relating to the planning process and prior knowledge (presented in section 4.2). These allowed us to develop a context-related understanding, enabling us to identify important structures and causal powers and mechanisms across cases.

The research process was carried out in two different phases.

During the Phase I (1) we performed a documental analysis, exploring plans, projects, laws, documents, transcripts, notes, as well as other relevant planning documents, using an open coding approach. We examined the documents and plans available that could affect public transport competitiveness (from the national to local contexts). Table 2 presents a summary of all the plans analyzed, including the National Strategies for Spatial Planning (NSSP, 2019), the National Guidelines for Mobility (IMTT, 2012), the Strategic Plan for Urban Development (SPUD), the Action Plan for Sustainable Mobility (APSM) or other Sustainable Urban Mobility Plans (SUMP), plus the Local Master Plan (MP) for each municipality and the Passenger Public Transport Contract (PPTC).

The documental analysis was followed by semi-structured interviews. This Second Phase (2) involved various agents from each municipality and consultants involved in the application of the new public transport regulatory systems (Table 2). All interviews were recorded, transcribed and subsequently analyzed. The interviews took place between June 2019 and May 2020, involving eleven agents from four municipalities and supra-municipal bodies.

With regard to the documents and plans, the interviewees were questioned about: the objectives and strategies; existing normative conflicts; how long-term objectives for land use and public transport are handled; and how said objectives favor or weaken the competitiveness of public transport compared to the private car. As far as the planning process is concerned, the interviewees were asked to describe the process, the key issues, knowledge, methods and the tools used to achieve the established goals, as well as the need for additional planning support tools. Particular attention was paid to who is involved in each process and how. Some of these are questions that received little attention in the planning research. For each study case, an interpretation scheme was devised to evaluate the relative competitiveness of public transport vis-à-vis the private transport mode in planning practice in the Portuguese context. 
Table 2. Planning documents selected and interviewees

\begin{tabular}{|c|c|c|}
\hline Case study & Documents & Interviewees \\
\hline Oporto & $\begin{array}{ll}\text { - } & \text { NSSP (2019) } \\
\text { - } & \text { MP Oporto (2020) } \\
& \text { under review } \\
\text { - } & \text { PPTC OMA (2020) } \\
\text { - } & \text { APSM OMA (2016) } \\
\end{array}$ & $\begin{array}{l}29 \text { October } 2019 \\
\text { - Head of Urban Planning Department }\end{array}$ \\
\hline Maia & $\begin{array}{l}\text { - } \text { NSSP (2019) } \\
\text { - } \text { SPUD Maia (2016) } \\
\text { - } \text { MP Maia (2016) under } \\
\text { review } \\
\text { - } \text { PPTC OMA (2020) } \\
\text { - } \text { APSM OMA (2016) } \\
\text { - } \text { APSM Maia (2016) } \\
\text { - SUMP Maia (2011a, } \\
\text { 2011b, 2012a, 2012b, } \\
\text { 2013a, 2013b) }\end{array}$ & $\begin{array}{l}22 \text { October } 2019 \text { first interview } \\
\text { - Head of Urban Planning Department } \\
\text { - Head of Mobility Department } \\
\text { - Specialist from the Mobility Department } \\
29 \text { May } 2020 \\
\text { Second interview (OMA) } \\
\text { - Consultant to OMA } \\
\text { - Chief of Transport Division } \\
\text { - Specialist OMA Transport Division }\end{array}$ \\
\hline $\begin{array}{l}\text { Santo Tirso (together with Trofa \& } \\
\text { Vila Nova de Famalicáo) }\end{array}$ & $\begin{array}{l}\text { - NSSP (2019) } \\
\text { - SPUD Ave (2014) } \\
\text { - MP Santo Tirso (2011) } \\
\text { under review } \\
\text { - APSM Santo Tirso } \\
\text { (2016) } \\
\text { - SUMP Santo Tirso, } \\
\text { Volume I (2011a), } \\
\text { Volume II (2011b), } \\
\text { Volume III (2011c), } \\
\text { Volume IV (2011d), } \\
\text { Volume V (2011e), } \\
\text { Volume VI (2016) }\end{array}$ & $\begin{array}{l}\text { 17 July } 2019 \text { First interview } \\
\text { - Municipal Director } \\
\text { - Head of Mobility and Transport for the Mu- } \\
\text { nicipality } \\
26 \text { June } 2019 \text { Second interview } \\
\text { - Consultant who developed the plan for tender- } \\
\text { ing }\end{array}$ \\
\hline Viseu & $\begin{array}{ll}\text { - } & \text { NSSP (2019) } \\
\text { - } & \text { SPUD Viseu (2015) } \\
\text { - } & \text { MP Viseu (2013) } \\
\text { - } & \text { PPTC Viseu (2015) }\end{array}$ & $\begin{array}{l}\text { 11 October } 2019 \\
\text { - Head of Mobility and Transport for the Mu- } \\
\text { nicipality } \\
\text { - Chief of Staff of Mobility and Transport for the } \\
\text { Municipality }\end{array}$ \\
\hline
\end{tabular}

Legend: NSSP - The National Strategies for Spatial Planning; SPUD - The Strategic Plan for Urban Development; MP Master Plan; RFPPT - Regulatory Framework for Passenger Public Transport; APSM - Action Plan for Sustainable Mobility; SUMP - Sustainable Urban Mobility Plan; PPTC - Passenger Public Transport Contract; OMA - Oporto Metropolitan Area.

\subsection{Portuguese transport and spatial planning instruments and documents}

The current spatial planning system in Portugal consists of a hierarchical structure of instruments (Cavaco et al., 2016; Davoudi et al., 2011), made up, among other instruments, by the National Program for Spatial Planning Policy, the Sectorial Plans, Special Plans and Regional Spatial Planning Plans (see Fig 1). However, competences such as promoting urban development and implementing land-use policies are essentially the responsibility of the municipalities - through Master Plans (MPs) and local projects - which results in urban planning at the municipal scale based on fragmented decision-making processes and limited inter-municipal coordination (Cavaco et al., 2016; Davoudi et al., 2011). While recommended, the drawing up of local and regional mobility plans is not mandatory in Portugal. As a consequence, higher-level authorities often face issues when endeavoring to implement transport and land-use policies. 


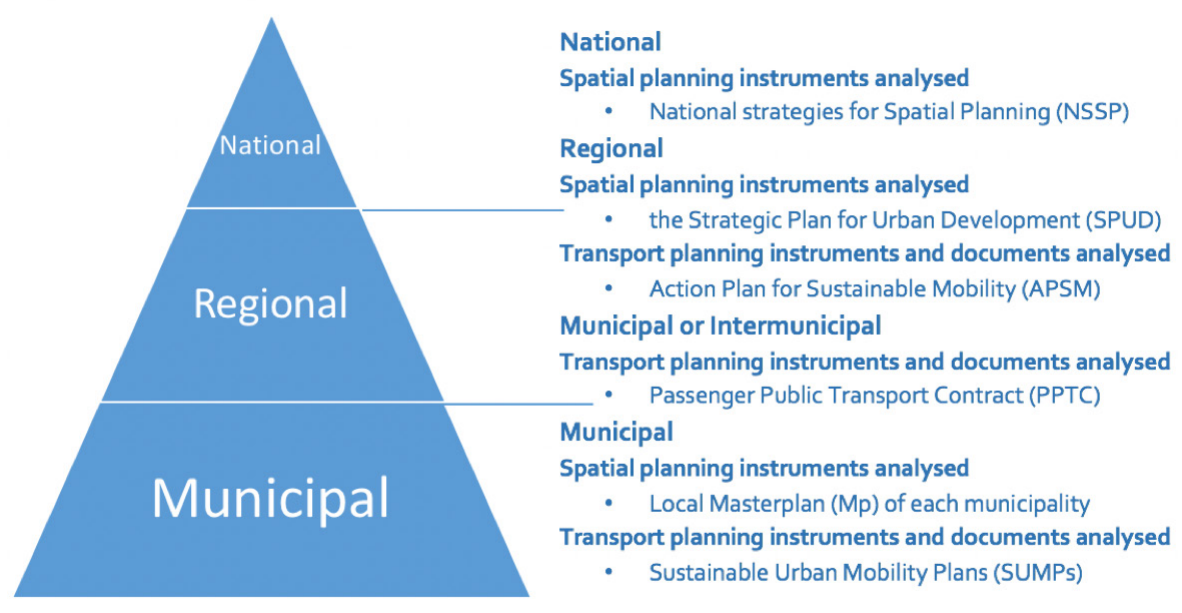

Figure 1. Hierarchical structure of spatial planning instruments analyzed

Following the introduction of the new RFPPT law (2015), Portuguese municipalities have launched a new tendering process for public transport operators. This decentralization of competences, for regular public transport services, from the central government to the respective municipalities, involves important decision-making strategies and costs. Municipalities were required to create new transport authorities and define the desired public transport service level. The challenge resided in achieving the appropriate transport governance model for a given spatial context. That context might not necessarily be limited by the administrative municipal boundaries or even those of inter-municipal communities. The new model seeks to find coherent mobility areas that can function as a network. It places greater importance on a functional region (commute area) over an administrative region. So, there is a possibility of configuring a variable geometry for the definition of transport authorities, which fits the spatial occupation model while meeting the mobility needs of the population. 


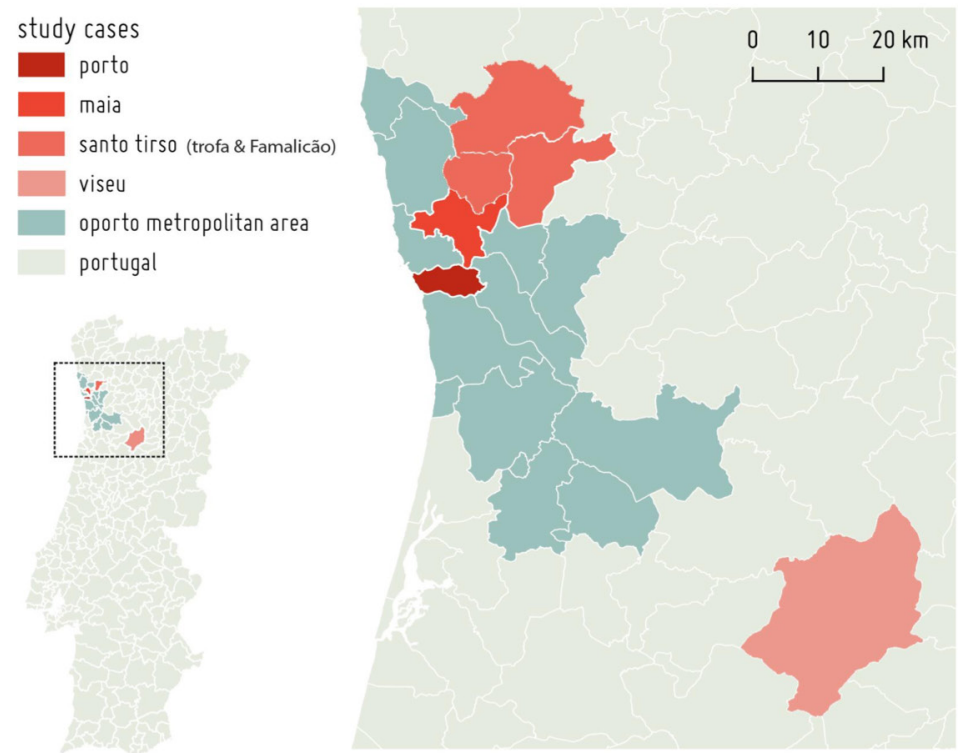

Figure 2. Case studies selected: Oporto, Maia, Santo Tirso (Trofa and Famalicão) and Viseu

\subsection{Case studies}

As pointed out above, the four Portuguese municipalities included in this research were Oporto, Maia, Santo Tirso (which shares its transport system with two other municipalities, Trofa and Vila Nova de Famalicão) and Viseu (Fig 2). These cases represent different Portuguese contexts in terms of dimension and complexity. They were chosen because they have four different and interesting decision-making processes in place which went beyond the simple adjudication of existing routes. Moreover, the population sizes also differed. ${ }^{2}$ Table 3 presents the spatial and transport characteristics of the municipalities analyzed.

Table 3. Municipalities' characteristics and modal split (Source: INE, 2011)

\begin{tabular}{|c|c|c|c|c|c|c|c|c|c|c|}
\hline & Pops & tion & Area & $\mathrm{km})$ & $\begin{array}{r}\text { Pop. } \\
\text { (inhal } \\
\text { sq. }\end{array}$ & $\begin{array}{l}\text { ensity } \\
\text { ants / } \\
\text { m) }\end{array}$ & & Moc & lit (\%) & \\
\hline Study Cases & 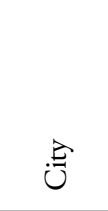 & 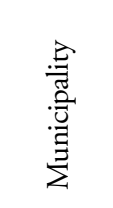 & 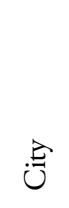 & 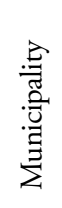 & 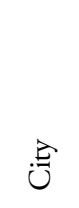 & 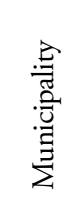 & 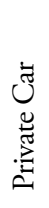 & 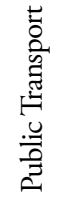 & 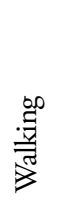 & 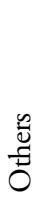 \\
\hline Oporto & 214,353 & 214,353 & 41 & 41 & 5,736 & 5,736 & 51 & 19 & 22 & 8 \\
\hline Maia & 40,134 & 136,390 & 10.4 & 83 & 3,853 & 1,643 & 70 & 13 & 11 & 6 \\
\hline $\begin{array}{l}\text { Santo Tirso (Trofa \& } \\
\text { Vila Nova de Famalicão) }\end{array}$ & 80,565 & 239,111 & 70 & 411 & 4,116 & 562 & 65 & 15 & 18 & 2 \\
\hline Viseu & 70,000 & 99,274 & - & 507 & - & 195 & 74 & 11 & 13 & 2 \\
\hline
\end{tabular}

${ }^{2}$ In line with the general aims of the IPTC project. 
Oporto Metropolitan Area (OMA) comprises seventeen municipalities, with a total of 2,040 sq. $\mathrm{km}$ and 1,700,000 inhabitants. Oporto is the central municipality of the OMA with around 214,000 inhabitants, representing the highest population density in the OMA with 5,736 inhabitants/sq. km. Maia, Santo Tirso, and Trofa are also part of the OMA. Maia has a population density of 1,635 inhabitants/sq. km. Santo Tirso is on the limits of the OMA (Fig 2) and has the lowest population density with 523 inhabitants/sq. km. It is located in the transition area between the Oporto Metropolitan Area and the Intermunicipal Community of the Ave Valley, which means that Santo Tirso municipality plays a unique role between these two strong urban conurbations. Viseu is not part of the OMA and has the lowest population density of the four selected cases with 195 inhabitants/sq. km. Oporto presents the lowest share of "car use" at 51\%, and Viseu the highest at 74\%.

Oporto and Maia have delegated the public transport tendering process to the metropolitan area authority. Nevertheless, in the case of Oporto and Maia, the main bus network, operated by STCP (Sociedade de Transportes Coletivos do Porto) and the Metro network, are not part of this tendering process, as their contracts are still valid. In the case of Santo Tirso, the decision was reached to restructure the public transport system together with two other neighboring municipalities (Trofa and Famalicão), instead of passing that responsibility on to a higher-level authority. Viseu assumed responsibility for the tendering process for its urban public transport system. However, the intercity network is under the responsibility of the intermunicipal community (IMC of Viseu Dão Lafốes).

\section{$4 \quad$ Exploring public transport competitiveness}

\subsection{Documental analysis}

Table 4 presents a summary of the main policy objectives and strategies identified for each of the four municipalities. Following the analysis structure used in the literature (Table 1), we will now explore the documental evidence of concerns and actions regarding public transport competitiveness, divided into: (i) public transport service quality; (ii) car restrictions; and (iii) land-use management measures.

\section{(i) public transport service quality improvement}

One of the most common measures across urban areas is the addition of segregated bus lanes and high-quality bus corridors. They ensure service reliability and enable buses to avoid traffic jams. All study cases in this research have introduced several high-quality bus corridors. However, they have not always included segregated bus lanes in the city center, due to space restrictions. The main aim of these measures is to improve bus speed and reliability, thus supporting an increase in public transport patronage. Segregated bus lanes enable cities to improve bus efficiency and attractiveness, as well as road safety.

Increased public transport supply and improved intermodal connections are other common measures. Maia improved bus stop access for pedestrians, cyclists and disabled people. Viseu is one of the largest municipalities studied (with an area of 507.10 sq. $\mathrm{km}$ ) and it adopted a DRT system (demand responsive transit), which is justified by an ageing population, rural matrix and urban sprawl. The principal objective was to provide a service for those who otherwise have limited or no public transport service (Interview, 11 October 2019). Santo Tirso also adopted a similar solution. 
Table 4. Main goals with effect on public transport competitiveness

\begin{tabular}{|c|c|}
\hline Case study & Land-use (car constraints) and quality of service \\
\hline Oporto* & $\begin{array}{l}\text { - Definition of high-quality bus corridors } \\
\text { - Expansion of the tram network } \\
\text { - Creation of infrastructure for cycling and better walking infrastructure } \\
\text { - New rules for urban densification } \\
\text { - Promote a new working model for the transport system } \\
\text { - Limits for private parking, maximums or minimums for new constructions } \\
\text { - Reinforce interfaces } \\
\text { - Replace parking spaces to other functions }\end{array}$ \\
\hline Maia & $\begin{array}{l}\text { - Creation of high-quality bus corridors - } 9 \text { by } 2023 \text { (APSM Maia, 2016: 55) } \\
\text { - Improvement of bus shelters } \\
\text { - Restructuring of the public space to prioritize transport modes other than the car } \\
\text { (APSM Maia, 2016: 49); } \\
\text { - Interfaces and network improvements (APSM Maia, 2016: 53) } \\
\text { - MP to reveal measures heavily focused on carbon-neutral development (Interview, } \\
20 \text { May 2020) } \\
\text { - Introduction of new parking pricing zones (PPTC OMA, 2020) }\end{array}$ \\
\hline $\begin{array}{l}\text { Santo Tirso (including Trofa and } \\
\text { Vila Nova de Fama-licão) }\end{array}$ & $\begin{array}{l}\text { - Increasing the coverage of the public transport system (APSM Santo Tirso, 2016) } \\
\text { - Improving services (APSM Santo Tirso, 2016) } \\
\text { - Car space restrictions (SUMP Santo Tirso, 2011a, volume I) } \\
\text { - DRT service (Demand Responsive Transit) (APSM Santo Tirso, 2016) } \\
\text { - Improvements in network access for pedestrians, cyclists and disabled people - barri- } \\
\text { er-free and better connection with public transport (SUMP Santo Tirso, 2011b, } \\
\text { 2011e, volume II and V) } \\
\text { - New circulation concept with the introduction of improved permeable and green } \\
\text { zones (SUMP Santo Tirso, 2011c, volume III) } \\
\text { - New cycling lanes (SUMP Santo Tirso, 2011c, volume III) } \\
\text { - Parking restrictions (SUMP Santo Tirso, 2011d, volume VI) }\end{array}$ \\
\hline Viseu & $\begin{array}{l}\text { - A new mobility system (MUV) that is an integrated mobility system including: } \\
\text { - A new bus line between the city center and the Hospital (PPTC Viseu, 2015) } \\
\text { - } 3 \text { new electric buses (PPTC Viseu, 2015) } \\
\text { - A demand responsive transit service (DRT) (SPUD, 2015: 5) } \\
\text { - 'Telebus', and an electric bus (SPUD Viseu, 2015: 5) } \\
\text { - Car parking management (SPUD Viseu, 2015: 6) } \\
\text { - Inclusion of parking space limitations in the city center (Interview, } 11 \text { October } \\
\text { 2019) } \\
\text { - New cycling network integrated with public transport system. (SPUD Viseu, 2015: } \\
\text { 1) } \\
\text { - Integrated ticketing and information systems network (SPUD Viseu, 2015: 6) }\end{array}$ \\
\hline
\end{tabular}

*Oporto Master Plan presently under review (s/d, 35-44); Oporto does not yet have mobility plans. Instead, we used the spatial plans for urban structure, transport structure and parking zones, public transport, soft modes; and the interview with the Head of the Urban Planning Department (29 October 2019)

It is important to point out that most measures were very much focused on optimizing service efficiency, resolving the overlaps of previous operators competing on certain routes. This, in itself, is not aimed at improving the relative competitiveness of public transport public transport (compared to the car). However, municipalities were mostly reinvesting operational savings into network expansion instead of cost reduction, leading to positive effects on competitiveness.

(ii) car restrictions

Road space, speed restrictions and parking space are the most common measures identified. Areas 
of limited access for cars is another example. Although very effective, this measure usually generates conflicts and may be difficult to implement without political commitment. Viseu adopted an area of limited access for cars so as to improve the quality of the public space in the city center.

Oporto proposes traffic calming measures through speed limits and $30 \mathrm{~km} / \mathrm{h}$ zones in residential areas. Other important traffic calming measures include road narrowing and deflections, through road design and implementation of physical elements that reduce speed, thus improving safety and comfort. Maia and Santo Tirso have adopted these measures. Parking policies have gradually become more restrictive, especially in urban centers. Parking management and pricing strategies are fundamental to car demand management. Porto will introduce maximum parking supply standards for private parking, replacing the traditional minimum parking supply standards fond in most Portuguese Master Plans.

\section{(iii) land-use management measures in support of public transport}

The National Strategies for Spatial Planning contain clear objectives based on polycentric development: a need to increase urban density and mixed uses in urban areas, as well as pedestrianization (NSSP, 2019, p. 51). Also, the reduction in travel distances and the need to travel, a more sustainable modal split and better mobility management are all equally important concerns in terms of the environment and quality of life of populations (NSSP, 2019, p. 69). However, none of these measures are made explicit in the Master Plans analyzed.

Fostering public transport use through land-use planning involves the management of existing land and new land development. It is usually achieved by controlling urban sprawl, improving density and mixed uses and the placement of public transport nodes. Public transport stations can be catalysts for greater accessibility in terms of land-use management through the upgrading of public spaces and new pedestrian and cycling routes. Santo Tirso adopted improvements in network access for pedestrians, cyclists and disabled people. The new improvements are encouraging for new rules and strategies for the new Master Plan. These objectives were complemented by goals of enhancing housing and activity density and the replacement of parking space by other functions (SUMP Santo Tirso - Volume VI, 2016). However, these objectives were also not made explicit in the Master Plan. Replacing parking space with other functions is one of the strategies Oporto has for its city center (MP, under review). The inclusion of mobility management measures in the Master Plan was explained by the absence of a Sustainable Urban Mobility Plan in Oporto by the city council agents interviewed.

Traditionally, urban transport planning in Portugal has focused mainly on the efficiency of the transport system itself. The new RFPPT law (2015) represents a profound change in the institutional and planning models for current public transport management in Portugal. Said law states that the planning, development, management, investment, funding and supervision of public transport systems must now be the responsibility of local councils. This provides the perfect opportunity to introduce new tools and strategies for public transport competitiveness vs the private car, namely at the spatial structure and land-use level. However, in the four cases we studied, mobility-based planning seems to be prioritized, which is in line with findings in other countries (Halden, 2011; Levinson, 2005; Proffitt et al., 2019).

It should be noted that, in all analyzed plans, the objectives regarding the relative competitiveness between public transport and car are not explicit. The current situation provides an opportunity to come up with new strategies and policies to effectively increase the competitiveness of public transport through land-use management (densification, distribution of activities, location of new infrastructures, parking constraints, etc.) and to improve the quality of the public transport service (increase supply, reliability, frequency, avoiding overlaps of routes, etc.). The municipalities are not necessarily making changes in order to improve public transport competitiveness. Often the plans and processes admit that 
better conditions of quality of the public transport system will result from the definition of one single operator for the network.

According to the consultants in Viseu and Santo Tirso, transport planning always follows the Master Plan (MP) and there is a general lack of understanding of the potential of territorial management, such as the locating activities and public services (ex. a new industrial area or school). There would still appear to be a knowledge gap in relation to how urban structure and public transport quality affect public transport competitiveness (Interview, 11 October 2019). Traditional transport models do not show if improvements benefit specific target groups. In reality, said models usually only focus on the performance of systems in general (Efthymiou et al., 2013; Mohino \& Ureña, 2020). A paradigm shift is still needed; urban and traffic planners should focus on the people and their needs, integrating the complex interactions between land-use and transport systems, instead of focusing simply in transport infrastructure (Poliak et al., 2017; Tennøy et al., 2016; Tennøy \& Øksenholt, 2018).

Similar findings have been found for Norwegian medium-sized cities (Skartland, 2021), in another study that is part of the same project reported on herein. That study found that, while Master Plans identified increasing public transport competitiveness versus the private car as a goal, all the Master Plans studied contained interventions that could contribute both negatively and positively to achieving this goal. On the whole, conflicting interventions often reduce rather than strengthen such competitiveness. The main explanations offered where related with conflicting goals and the prioritization of other goals. The possible effects of interventions also largely depend on context, dimension and location (Skartland, 2021).

\subsection{Planning process and knowledge}

Our research suggests that the municipalities are concerned with improving the competitiveness of public transport (as well as walking and cycling) vis-à-vis the private car. Previously, public transport services were ensured by different private operators competing over different routes and offering different services. The integration of all services under one single operator for the tendering process allowed for the optimization of routes and services. Nonetheless, the complex power systems involved in that process, the lack of data and of expert knowledge, and the absence of tools supporting decision-making have all weakened this opportunity. 
Table 5. Planning practice

\begin{tabular}{|c|c|c|}
\hline Case study & Institutions & Expert knowledge \\
\hline Oporto* & $\begin{array}{l}\text { - The tendering process for public transport } \\
\text { is responsibility of the OMA. } \\
\text { - There is currently no formal plans for } \\
\text { public transport. } \\
\text { - Local Master Plan under development } \\
\text { without the involvement of the Municipal } \\
\text { Transport Department. }\end{array}$ & $\begin{array}{l}\text { - The OMA hired an external consultant to } \\
\text { work together with the planning practitio- } \\
\text { ners from OMA for the tendering process. }\end{array}$ \\
\hline Maia & $\begin{array}{l}\text { - The tendering process for public transport } \\
\text { is the responsibility of the OMA. } \\
\text { - The Urban Planning and the Mobility } \\
\text { Departments are working together in the } \\
\text { development of the mobility plans. }\end{array}$ & $\begin{array}{l}\text { - The OMA hired an external consultant to } \\
\text { work together with the planning practitio- } \\
\text { ners from OMA for the tendering process. } \\
\text { - The practitioners from the municipality } \\
\text { are currently learning, from OMA, the } \\
\text { new tendering process. }\end{array}$ \\
\hline $\begin{array}{l}\text { Santo Tirso (Trofa \& } \\
\text { Vila Nova de Fa-malicão) }\end{array}$ & $\begin{array}{l}\text { - The tendering process for public transport } \\
\text { is responsibility of Santo Tirso, Trofa and } \\
\text { Vila Nova de Famalicão municipalities. } \\
\text { - The councils jointly hired a consulting } \\
\text { company to develop the strategy for the } \\
\text { tendering process and the mobility plans. }\end{array}$ & $\begin{array}{l}\text { The council hired an external consultant } \\
\text { for the tendering process and for the } \\
\text { development of the mobility plans. } \\
\text { - The planning practitioners from the } \\
\text { municipality are now learning from the } \\
\text { external consultant. }\end{array}$ \\
\hline Viseu & $\begin{array}{l}\text { The tendering process for public transport } \\
\text { is the responsibility of Viseu city council. } \\
\text { - It structured actions aimed at complying } \\
\text { with the new law and are now develop- } \\
\text { ing the plans. (External Consultant under } \\
\text { Viseu City Council management developed } \\
\text { the contract for tendering). }\end{array}$ & $\begin{array}{l}\text { The council hired an external consultant } \\
\text { for the tendering process. } \\
\text { - The practitioners from the municipality } \\
\text { are learning from the external consultant. }\end{array}$ \\
\hline
\end{tabular}

One of the main problems is the relationships of power between the various institutions involved, particularly higher-level authorities and municipalities (Table 5). The RFPPT (2015) introduces strong encouragement for the promotion of synergies between the different authority levels. The same goes for the plans and policies/actions they may produce. This changes the way that current planning practice is being developed. Our research also found evidence of such conflicts within the same institution. In some cases, the spatial development and transport departments worked separately. This supports earlier evidence with regard to planning practice, suggesting thar conflicts are often embedded in the processes (Næss et al., 2013; Tennøy \& Øksenholt, 2018).

Among interviews, both local practitioners and policy-makers are in agreement on the lack of available data and specific training to face these new responsibilities. Indeed, the lack of available data in the decision-making process was declared by all agents involved, ranging from the simple patronage levels for existing routes to the general travel behavior and preferences of inhabitants. According to consultants interviewed, demand and service data were not required from operators until the change in the legislation (Interview, May 20, 2020). When these were faced with the requirement to provide data for the tendering process, local authorities found that operators were mostly unaware of basic information such as, exact levels of patronage, or had no internal procedures to manage an updated datasets on route layouts or timetables for their services. In addition to these restrictions, municipalities also have limited spatial datasets on urban activities and even road layouts. We found no evidence of any travel surveys done to overcome data limitations. In the absence of reliable data on demand and supply, some authorities used the available information on existing network layouts as a primary blueprint for the new service making minor adjustments to improve coverage or frequency levels. More significant changes to the 
existing network and service level were found in cases bringing together strong technical support from consultants and political will to make the said changes. Even facing similar data restrictions, consultants were able to use available data (mainly population distribution and location of main travel generators) to build a spatial strategy for the new public transport network.

Furthermore, many authorities lack specific technical knowledge on public transport operation, planning, and most of the other functions that emerged with the new regulatory framework. In order to deal with this gap, in all cases the tendering process was organized into different stages that could be improved and adjusted as the process was being carried out. The first stage generally involved applying for external support. The municipalities either delegate responsibility to higher level authorities (Metropolitan Areas or Intermunicipal Communities ${ }^{3}$ ) or resort to external consultants.

According to the practitioners from the municipality of Viseu, the public transport tendering process is mostly led by the consultant, given their considerable know-how. They also exchange information with the intermunicipal community (IMC of Viseu Dão Lafôes) and the Portuguese Institute for Mobility and Transports (IMT). ${ }^{4}$ This process brings with it new challenges for all the agents involved. In this case, given the existing time constraints, the articulation between the aforementioned authorities did not work properly. For instance, intercity routes were only assessed after the document for tendering was ready. The argument was that the process was being implemented in reverse order. In other words, first, they implement the measures and then develop the plans. This complicated process seems to result from the need to follow specific requirements and the short timeframes for implementation (Interview, 11 October 2019).

Santo Tirso (together with Trofa and Famalicão) had to deal with several challenges, having to create a new governance system in a co-learning process. The budget uncertainties and time investment required for this joint process proved to be significant challenges to the endeavor. The chosen consultancy company found it difficult to plan some routes in accordance with land-use, given that, for instance, most of the network provides transport to schools and schools are not always attended by children of the same area, meaning that a bus route in this case is not as efficient as it could be (Interview, 26 June 2019). Here too, information was lacking on origin-destination of the school children in question.

Several planning practitioners and even policy-makers acknowledged their prior lack of understanding of the potential of land-use planning for mobility management. Nevertheless, most of them stated that they now see land-use instruments differently. So, a learning process underlies the planning process. Planning practitioners and policy-makers also acknowledged a lack of specific training in order to face these new responsibilities and process. The four cases, suggest that current public transport planning and policy-making processes in Portugal are still undergoing significant changes (Table 5). The new system was shaped mostly by the available budget, thus limiting its potential to be more competitive. The shortcomings of existing planning support tools may also be an area for essential improvement (Bertolini, 2007; Bertolini et al., 2005). Municipalities and higher-level public authorities are working hard, and most importantly, they are very open to adapting. Now that the tendering processes have been launched (and deadlines met), local authorities seem to be recognizing the previously missed potential of the process, thus empowering them with the ability to contribute improving public transport competitiveness vis-à-vis the private car.

The evident lack of technical know-how experienced during this implementation, together with the interest demonstrated in technical support tools by most participants, in particular those revealing relative competitiveness, represents pressing challenges for research.

\footnotetext{
${ }^{3}$ In Portugal there is no regional government body besides the inter-municipal associations called intermunicipal communities. These bodies have no official budget and as such are entirely dependent on the respective individual municipalities.

${ }^{4}$ The IMT is the main institution for mobility and transport in Portugal, and it is responsible for passing down the information the municipalities need, as well as the laws to follow.
} 


\section{$5 \quad$ Lessons learned}

The new regulatory framework has potential to affect a shift in public transport strategy from the provision of minimal services to competitive approaches, thus supporting an increase in the numbers of public transport choice riders. It provides the opportunity to bring decision-making closer to those with greater accountability for providing for the needs of the population, while also bringing together land use, transport and public transport planning under one and the same geographical scale and public authority. Nevertheless, local authorities now face massive challenges in trying to cope with increasing (and increasingly complex) financial, operational, technical and strategic responsibilities. The risk that these responsibilities may overwhelm local authorities, leading them to relegate in importance strategic decision-making, is concerning.

Despite the potential for bringing decision-making to a local level, it should be pointed out that public transport networks do not adhere to administrative boundaries and thus suffer similar constraints to those already identified in traditional land-use and transport planning. It is also important to point out that the new responsibilities required local authorities to develop a wide range of skills in a very short period of time (for instance, skills relating to public transport finances, operation, service levels, patronage and even public tendering processes). Considering these two constraints, it is easy to understand why many local authorities decided to delegate their role as the public transport authority to supramunicipal bodies (such as metropolitan areas or intermunicipal communities). In all the case studies analyzed herein, external consultants were involved in the process to overcome limitations in technical know-how. Although these solutions (delegation and consultancy services) are reasonable within this context, they have contributed to undermining coordination between different areas of responsibility and technical fields, by increasing the number of people directly or indirectly involved in the processes. It is easy to understand that the complexity of the public transport tendering process was a constraint to a more holistic planning approach (involving land-use and wider mobility strategies). Regardless of the positive steps taken, there is still a long way to go in the development of plans and policy-making at the intersectoral coordination level.

Our results suggest that know-how in several fields is a key factor in this process and that development of said know-how should be a priority. Ignoring the importance of developing technical skills brings with it the risk of giving rise to flawed institutional arrangements and processes from the outset, which might be harder to correct in the future. More research is needed in other contexts, in order to explore how these risks have risen and how they can be avoided. Research on planning support tools for strategic thinking was also recognized as being useful by practitioners, such as tools revealing relative competitiveness. ${ }^{5}$

Although all the municipalities acknowledge the importance of improving public transport competitiveness, they are generally still far from regarding public transport as a direct competitor to the car. Objectives are clearly aligned with improving competitiveness, in general terms, but are still based on the provision of minimal services. Also, the objectives are dominated by concerns of economic viability following the transfer of financial responsibility from the national government to the local authorities. The higher the congestion problems of a city, the greater the acknowledgement that public transport services must do more than provide minimal services; however, this has not become a priority yet. The novelty of the process and of considering the public transport network as a whole has garnered all the attention, leaving little room for goals of higher-order strategy levels. Some examples of complementary land-use

\footnotetext{
${ }^{5}$ For a review on such tools see Silva et al. (2020), a report of the IPTC project.
} 
and mobility policies can be found, although not necessarily included to improve public transport competitiveness. Conflicting policies were also identified. Further research is needed to provide support for a smoother and swifter change in public transport planning process and strategy, able to harvest the full potential of the change of the regulatory framework.

\section{Acknowledgements}

The authors gratefully thanks Tamara Bicalho and we thank all interviewed who had participated in this research. This work was financed by The Norwegian Research Council, the KLIMAFORSK-program, grant number 268086 . 


\section{References}

APSM Maia. (2016). Action plan for sustainable mobility. Maia, Portugal: Maia City Council.

APSM OMA. (2016). Action plan for sustainable mobility. Porto, Portugal: Porto Metropolitan Area.

APSM Santo Tirso. (2016). Action plan for sustainable mobility. Santo Tirso, Portugal: Santo Tirso City Council.

Banister, D. (1994). Reducing the need to travel through planning. The Town Planning Review, 65(4), 349-354.

Banister, D. (2008). The sustainable mobility paradigm. Transport Policy, 15(2), 73-80. https://doi. org/10.1016/j.tranpol.2007.10.005

Banister, D., Crist, P., \& Perkins, S. (2015). Land transport and how to unlock investment in support of "Green Growth"(OECD green growth papers). Paris: OECD.

Benenson, I., Martens, K., Rofé, Y., \& Kwartler, A. (2011). Public transport versus private car GISbased estimation of accessibility applied to the Tel Aviv metropolitan area. The Annals of Regional Science, 47(3), 499-515. https://doi.org/10.1007/s00168-010-0392-6

Bertolini, L. (2007). Evolutionary urban transportation planning: An exploration. Environment and Planning A, 39(8), 1998-2019. https://doi.org/10.1068/a38350

Bertolini, L. (2020). From "streets for traffic" to "streets for people": Can street experiments transform urban mobility? Transport reviews, 40(6), 734-753. https://doi.org/10.1080/01441647.2020.1761 907

Bertolini, L., Le Clercq, F., \& Kapoen, L. (2005). Sustainable accessibility: A conceptual framework to integrate transport and land use plan-making. Two test applications in the Netherlands and a reflection on the way forward. Transport Policy, 12(3), 207-220. https://doi.org/10.1016/j.tranpol.2005.01.006

Buehler, R., \& Hamre, A. (2015). The multimodal majority? Driving, walking, cycling, and public transportation use among American adults. Transportation, 42(6), 1081-1101. https://doi.org/10.1007/ s11116-014-9556-z

Buehler, R., \& Pucher, J. (2011). Making public transport financially sustainable. Transport Policy, 18(1), 126-138. https://doi.org/10.1016/j.tranpol.2010.07.002

Cavaco, C., Oliveira, A. G., Gusmão, C., Branco, M. C., Nicolau, M., França, L., ... Gaspar, R. (2016). Habitat III - Portugal national report. Lisbon, Portugal: General Directorate of the Territory.

Cervero, R. (2013). Linking urban transport and land use in developing countries. Journal of Transport and Land Use, 6(1), 7-24. https://doi.org/10.5198/jtlu.v6i1.425

Cervero, R. (2014). Transport infrastructure and the environment in the global South: Sustainable mobility and urbanism. Journal of Regional and City Planning, 25(3), 174-191.

Cervero, R., \& Kockelman, K. (1997). Travel demand and the 3Ds: Density, diversity, and design. Transportation Research Part D: Transport and Environment, 2(3), 199-219. https://doi.org/10.1016/ S1361-9209(97)00009-6

Curtis, C., \& Scheurer, J. (2010). Planning for sustainable accessibility: Developing tools to aid discussion and decision-making. Progress in Planning, 74(2), 53-106. https://doi.org/10.1016/j.progress.2010.05.001

Curtis, C., \& Scheurer, J. (2017). Performance measures for public transport accessibility: Learning from international practice. Journal of Transport and Land Use, 10(1), 93-118. https://doi.org/10.5198/ jtlu.2016.683

Davoudi, S., Gunn, Z., Trip, J., Madanipour, A., Megginson, C., Stead, D., Sturzaker, J. (2011). Transforming urban planning policies - Case studies of Oporto, Newcastle, Stockholm and Vienna. SUMEWorking Paper 4.3. Newcastle upon Tyne. www.sume.at/project_downloads 
Efthymiou, D., Antoniou, C., \& Waddell, P. (2013). Factors affecting the adoption of vehicle sharing systems by young drivers. Transport Policy, 29, 64-73. https://doi.org/10.1016/j.tranpol.2013.04.009

European Commission. (2007). Regulation (EC) No 1370/2007 of the European Parliament and of the Council of 23 October 2007 on public passenger transport services by rail and by road and repealing Council Regulations (Nos 1191/69 and 1107/70). Brussels: European Commission.

Freudendal-Pedersen, M. (2020). Sustainable urban futures from transportation and planning to networked urban mobilities. Transportation Research Part D: Transport and Environment, 82, 102310. https://doi.org/10.1016/j.trd.2020.102310

Halden, D. (2011). The use and abuse of accessibility measures in UK passenger transport planning. Research in Transportation Business \& Management, 2, 12-19. https://doi.org/10.1016/j. rtbm.2011.05.001

Hitge, G., \& Vanderschuren, M. (2015). Comparison of travel time between private car and public transport in Cape Town. Journal of the South African Institution of Civil Engineering, 57(3), 35-43. https://doi.org/10.17159/2309-8775/2015/v57n3a5

Holden, E., Linnerud, K., Banister, D., Schwanitz, V. J., \& Wierling, A. (2017). The imperatives of sustainable development: Needs, justice, limits (pp. 213-226). Abingdon-on-Thames, Oxfordshire, England: Routledge. https://doi.org/10.1002/sd.1647

Ibraeva, A., de Almeida Correia, G. H., Silva, C., \& Antunes, A. P. (2020). Transit-oriented development: A review of research achievements and challenges. Transportation Research Part A: Policy and Practice, 132, 110-130. https://doi.org/10.1016/j.tra.2019.10.018

INE. (2011). National Cencus Data from 2011. Instituto Nacional de Estatística www.ine.pt

IMTT. (2012). National guidelines for mobility. Mobility package - Territory accessibility and mobility management (Territory 63). Lisbon, Portugal: Institute of Mobility and Transportation.

Kenyon, S., \& Lyons, G. (2003). The value of integrated multimodal traveler information and its potential contribution to modal change. Transportation Research Part F: Traffic Psychology and Behavior, 6(1), 1-21. https://doi.org/10.1016/S1369-8478(02)00035-9

Lee, H., Park, H. C., Kho, S. Y., \& Kim, D. K. (2019). Assessing transit competitiveness in Seoul considering actual transit travel times based on smart card data. Journal of Transport Geography, 80, 102546. https://doi.org/10.1016/j.jtrangeo.2019.102546

Levinson, D. (2005). The evolution of transport networks. In Handbook of transport strategy, policy and institutions. Bingley, UK: Emerald Group Publishing. https://doi.org/10.1108/9780080456041011

Li, L., Bai, Y., Song, Z., Chen, A., \& Wu, B. (2018). Public transportation competitiveness analysis based on current passenger loyalty. Transportation Research Part A: Policy and Practice, 113, 213-226. https://doi.org/10.1016/j.tra.2018.04.016

Litman, T. (2011). The first casualty of a non-existent war evaluating claims of unjustified restrictions on automobile use, and a critique of "Washington's war on cars and the suburbs. "Victoria Transport Policy Institute. www.vtpi.org/carwars.pdf

Litman, T. (2018). Evaluating public transit benefits and costs. Victoria, BC, Canada: Victoria Transport Policy Institute.

Marquet, O., \& Miralles-Guasch, C. (2018). Resilient territories and mobility adaptation strategies in times of economic recession: Evidence from the metropolitan region of Barcelona, Spain 2004-2012. European Urban and Regional Studies, 25(4), 345-359. https://doi.org/10.1177/0969776417703158

Miralles-Guasch, C., Melo, M. M., \& Sarda, O. M. (2014). On user perception of private transport in Barcelona Metropolitan area: An experience in an academic suburban space. Journal of Transport Geography, 36, 24-31. https://doi.org/10.1016/j.jtrangeo.2014.02.009

Mohino, I., \& Ureña, J. M. (2020). Mobility, housing and labor markets in times of economic crises. 
Regional Studies, 54(4), 443-449. https://doi.org/10.1080/00343404.2020.1711879

MP Maia. (2016, under review). Master plan. Maia, Portugal: Maia City Council.

MP Oporto. (2020, under review). Master plan. Porto, Portugal: Porto Metropolitan Area.

MP Santo Tirso. (2011, under review). Master plan. Santo Tirso, Portugal: Santo Tirso City Council.

MP Viseu. (2013). Master plan. Viseu, Portugal: Viseu City Council.

Næss, P. (2006). Accessibility, activity participation and location of activities: Exploring the links between residential location and travel behavior. Urban Studies, 43(3), 627-652. https://doi. org/10.1080/00420980500534677

Næss, P., Hansson, L., Richardson, T., \& Tennøy, A. (2013). Knowledge-based land use and transport planning? Consistency and gap between "state-of-the-art" knowledge and knowledge claims in planning documents in three Scandinavian city regions. Planning Theory \& Practice, 14(4), 470-491. https://doi.org/10.1080/14649357.2013.845682

NSSP. (2019). The national strategies for spatial planning. Lisbon, Portugal: Action Program Ministry, National Spatial Planning Policy Program.

Papagiannakis, A., Vitopoulou, A., \& Yiannakou, A. (2021). Transit-oriented development in the southern European city of Thessaloniki introducing urban railway: Typology and implementation issues. European Planning Studies, 29(1), 117-141. https://doi.org/10.1080/09654313.2020.1724267

Pinho, P., Silva, C., Giulietti, F., Reis, J. P., Torres, M., \& Naess, P. (2015). MOPUS - Mobility patterns and urban structure. Farnham, UK: Ashgate Publishing.

Poliak, M., Poliakova, A., Mrnikova, M., Šimurková, P., Jaśkiewicz, M., \& Jurecki, R. (2017). The competitiveness of public transport. Journal of Competitiveness, 9, 81-97. https://doi.org/10.7441/ joc.2017.03.06

PPTC OMA. (2020). Passenger public transport contract. Porto, Portugal: Porto Metropolitan Area.

PPTC Viseu. (2015). Passenger public transport contract. Viseu, Portugal: Viseu City Council. http:// www.cm-viseu.pt/assemunicipal/30112015/anexo1.pdf

Proffitt, D. G., Bartholomew, K., Ewing, R., \& Miller, H. J. (2019). Accessibility planning in American metropolitan areas: Are we there yet? Urban Studies, 56(1), 167-192. https://doi. org/10.1177/0042098017710122

Pucher, J., \& Buehler, R. (2017). Cycling toward a more sustainable transport future. Transport Reviews, 37(6), 689-694. https://doi.org/10.1080/01441647.2017.1340234

RFPPT. (2015). Regulatory framework for passenger public transport. Lisbon, Portugal: Assembly of the Republic, Legal Regime of the Public Service for Passenger Transport. https://data.dre.pt/eli/ lei/52/2015/06/09/p/dre/pt/html

Sallis, J. F., Cutter, C. L., Lou, D., Spoon, C., Wilson, A. L., Ding, D., ... Orleans, C. T. (2014). Active living research. American Journal of Preventive Medicine, 46, 195-207. https://doi.org/10.1016/j. amepre.2013.10.019

Silva, C., Castro, N., Bicalho, T., \& Cadima, C. (2020) Using accessibility measures to reveal public transport competitiveness (Accessibility measures final report for the IPTC project). Porto, Portugal: University of Porto, CITTA. https://citta.fe.up.pt/assets/pdf/projects/2020_final-report_iptc.pdf

Skartland, E. G. (2021). How interventions in master plans affect public transport competitiveness versus cars: A case study of two small and two medium-sized city regions. Urban, Planning and Transport Research. https://doi.org/10.1080/21650020.2020.1862701

SPUD Ave. (2014). The strategic plan for urban development (Final report). Ave, Portugal: Intermunicipal Community of Ave.

SPUD Maia. (2016). The strategic plan for urban development. Maia, Portugal: Maia City Council. SPUD Viseu. (2015). The strategic plan for urban development. Viseu, Portugal: Viseu City Council. SUMP Maia. (2011a). Sustainable urban mobility plan. Maia, Portugal: City Council of Maia. 
SUMP Maia. (2011b). Sustainable urban mobility plan (Field work schedule report). Maia, Portugal, Maia City Council.

SUMP Maia. (2012). Sustainable urban mobility plan (Characterization and diagnostic report). Maia, Portugal: Maia City Council.

SUMP Maia. (2012). Sustainable urban mobility plan (Scenario and evolution of mobility patterns report). Maia, Portugal: Maia City Council.

SUMP Maia. (2013a). Sustainable urban mobility plan (Characterization and diagnostic report). Maia, Portugal: Maia City Council.

SUMP Maia. (2013b). Sustainable urban mobility plan (Final report). Maia, Portugal: Maia City Council.

SUMP Santo Tirso. (2011a). Sustainable urban mobility plan, volume 1 (Inclusive accessibility study and good practice manual). Santo Tirso, Portugal: Santo Tirso City Council.

SUMP Santo Tirso. (2011b). Sustainable urban mobility plan, volume II (Study of the restructuring of the public road transport network and service). Santo Tirso, Portugal: Santo Tirso City Council.

SUMP Santo Tirso. (2011c). Sustainable urban mobility plan, volume III: The bike path network. Santo Tirso, Portugal: Santo Tirso City Council.

SUMP Santo Tirso. (2011d). Sustainable urban mobility plan, volume IV: Basic program at the door offour schools and pedestrian system. Santo Tirso, Portugal: Santo Tirso City Council.

SUMP Santo Tirso. (2011e). Sustainable urban mobility plan, volume V: Descriptive and justificative memory. Santo Tirso, Portugal: Santo Tirso City Council.

SUMP Santo Tirso. (2016). Sustainable urban mobility plan Volume VI: Hierarchy of the road network, concept of circulation, parking policy. Santo Tirso: Santo Tirso City Council.

Tennøy, A., \& Øksenholt, K. V. (2018). The impact of changed structural conditions on regional sustainable mobility planning in Norway. Planning Theory \& Practice, 19(1), 93-113. https://doi.org/1 $0.1080 / 14649357.2017 .1408135$

Tennøy, A., Hansson, L., Lissandrello, E., \& Næss, P. (2016). How planners' use and non-use of expert knowledge affect the goal achievement potential of plans: Experiences from strategic land-use and transport planning processes in three Scandinavian cities. Progress in Planning, 109, 1-32. https:// doi.org/10.1016/j.progress.2015.05.002

TFL. (2017). Guide to the healthy streets indicators delivering the healthy streets approach about transport for London. London: Transport for London.

Thomas, R., \& Bertolini, L. (2017). Defining critical success factors in TOD implementation using rough set analysis. Journal of Transport and Land Use, 10(1), 139-154. https://doi.org/10.5198/ jtlu.2015.513

van Lierop, D., \& El-Geneidy, A. (2018). Is having a positive image of public transit associated with travel satisfaction and continued transit usage? An exploratory study of bus transit. Public Transport, 10(2), 241-256. https://doi.org/10.1007/s12469-018-0175-5 